\title{
Angioedema secondary to amlodipine and lisinopril: a documented progression
}

\author{
Ari Morgenthau, ${ }^{1}$ Euiseok Kim ${ }^{1,2}$
}

'Department of Medicine, Dalhousie University, Halifax, Nova Scotia, Canada ${ }^{2}$ Division of General Internal Medicine, Dalhousie University, Halifax, Nova Scotia, Canada

\section{Correspondence to Dr Ari Morgenthau, a.morgenthau@dal.ca}

Accepted 22 August 2019

\section{Check for updates}

(C) BMJ Publishing Group Limited 2019. No commercial re-use. See rights and permissions. Published by BMJ.

To cite: Morgenthau A,
Kim E. BMJ Case Rep
2019;12:e232019.
doi:10.1136/bcr-2019-
232019

\section{DESCRIPTION}

A 50-year-old man with a polycystic kidney disease, awoke from sleep with unilateral jaw swelling. As demonstrated in the accompanying figure 1 , the oedema progressed over a period of 6 hours to involve his lips and tongue. On involvement of his tongue and development of slurred speech, he presented to an emergency department and required emergent intubation for airway protection. Prompt administration of steroids, epinephrine, ranitidine and diphenhydramine had no effect. Pertinent clinical findings on presentation included oedema of the jaw, lips, tongue and eyelids. Rash, urticaria, flushing and bronchospastic breath sounds, typical of an allergic reaction, were absent. Notably, the patient and his father had a history of unexplained jaw swelling which would self resolve within hours to days. The patient could not recall when the intermittent swelling had started but noted increased frequency over the last 4-6 months, during which time he was started on amlodipine. Additional medications include lisonipril, allopuriniol, venlafaxine

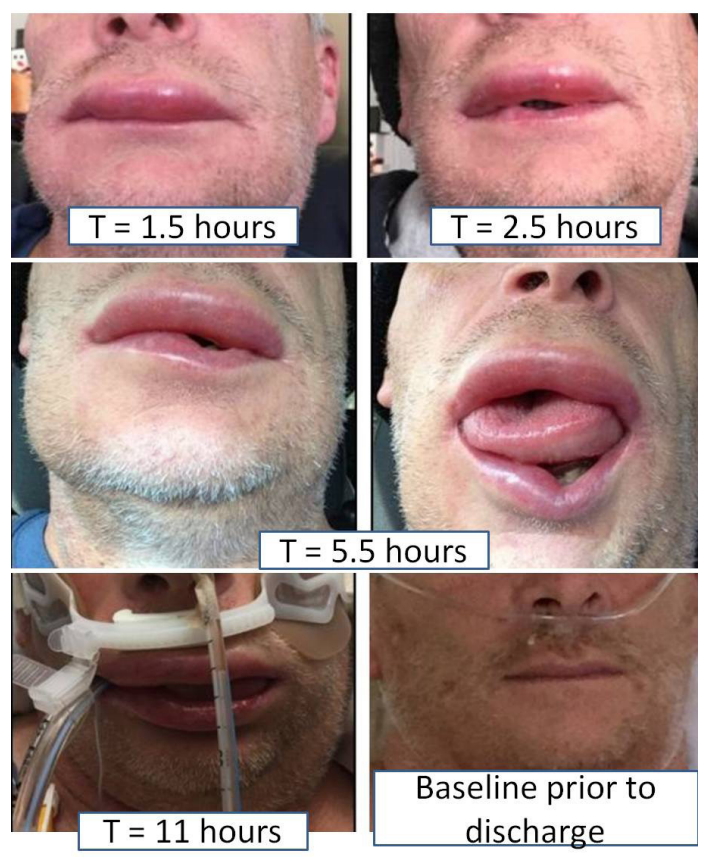

Figure 1 A timelapse of angioedema using pictures provided by the patient to the care team. Pictures show progression of the presentation starting at 1.5 hours, 2.5 hours, 5.5 hours, 11 hours and following return to baseline after 5 days days. As described in the case symptoms were not responsive to therapy with epinepherine, steroids, rantidine and diphenhydramine; but improved with gradually following discontinuation of amlodipine and lisinopril. and talvaptan. Given the patient's presenting features in combination with lack of therapeutic response, the presumptive diagnosis of angioedema was made. Complement factor 1, 3, 4 and as well as complement factor 1 inhibitor levels were normal, essentially ruling out hereditary angioedema. The patient's lisinopril and amolidipine, the likely causative agents, were subsequently discontinued with notable improvement of facial oedema over the next 4 days.

The presentation of non-heretidary, non-allergic angioedema is often attributed to medications such as ACE inhibitors. ${ }^{1}$ Excess bradykinin, causes increased vasodilation and capillary permeability, resulting in the presenting oedema. ACE inhibitors block the ACE, preventing the secondary function of bradykinin degredation. More recently, calcium channel blockers have also been implicated in angioedema; however, the mechanism is still unknown. ${ }^{23}$ Given the increased frequency of this patient's facial oedema, following introduction of amlodipine his angioedema was attributed to a combination of two precipitating agents and mechanisms: amlodipine and lisinopril. Two months after discharge, the patient expired from unrelated causes. There had been no recurrence of angioedema.

\section{Learning points}

- While angioedema has similarities to an anaphylactic reaction, it can be distinguished by its lack of rash, urticaria, bronchospastic breath sounds and poor response to treatment.

- Angioedema can have a delayed presentations months to years after the starting the inciting agents, and can present with progressive and recurrent symptoms.

- Although ACEi are a well characterised cause of angioedema other medications have been attributed such as calcium channel blockers and dipeptidyl peptidase 4 (DDP-4) inhibitors.

Contributors Both AM and EK cared for this patient, and performed the above investigations. The manuscript was prepared by AM, and reviewed/revised by EK.

Funding The authors have not declared a specific grant for this research from any funding agency in the public, commercial or not-for-profit sectors.

Competing interests None declared.

Patient consent for publication Next of kin consent obtained.

Provenance and peer review Not commissioned; externally peer reviewed.

\section{REFERENCES}

1 Gandhi J, Jones R, Teubner D, et al. Multicentre audit of ACE-inhibitor associated angioedema (MAAAA). Aust Fam Physician 2015;44:579. 


\section{Images in...}

2 Southward J, Irvine E, Rabinovich M. Probable amlodipine-induced angioedema. Ann Pharmacother 2009;43:772-6.

3 Kuruvilla ME, Sanan N. Amlodipine-induced angioedema: An unusual complication of a common medication. Allergy Rhinol 2018;9.

Copyright 2019 BMJ Publishing Group. All rights reserved. For permission to reuse any of this content visit

https://www.bmj.com/company/products-services/rights-and-licensing/permissions/

BMJ Case Report Fellows may re-use this article for personal use and teaching without any further permission.

Become a Fellow of BMJ Case Reports today and you can:

- Submit as many cases as you like

- Enjoy fast sympathetic peer review and rapid publication of accepted articles

Access all the published articles

Re-use any of the published material for personal use and teaching without further permission

Customer Service

If you have any further queries about your subscription, please contact our customer services team on +44 (0) 2071111105 or via email at support@bmj.com.

Visit casereports.bmj.com for more articles like this and to become a Fellow 